\title{
ЗМІНИ ЦИТОКІНОВОГО ПРОФІЛЮ СИРОВАТКИ КРОВІ У ЩУРІВ ЗА УМОВИ ПАСИВНОГО ТЮТЮНОКУРІННЯ НА ТЛІ ТРИВАЛОГО ВВЕДЕННЯ НАТРІЮ ГЛУТАМАТУ У ВІКОВОМУ АСПЕКТІ
}

\section{Зміни цитокінового профрілю сироватки крові у щурів за умови пасивного тютюнокуріння на тлі тривалого введення натрію глутамату у віковому аспекті}

\section{Н. В. Гецько, І. Я. Криницька}

Тернопільський національний медичний університет імені І. Я. Горбачевського МОЗ України

Резюме. Всесвітня організація охорони здоров'я розглядає тютюнокуріння як глобальну медико-соціальну проблему, а активне застосування штучних харчових добавок у харчовій промисловості викликає неоднозначне ставлення щодо їх безпеки відносно здоров'я людини, тому дослідження молекулярних механізмів токсичності ізольованої та поєднаної дії тютюнового диму і натрію глутамату є одним з актуальних питань у сучасній науці.

Мета дослідження - вивчити зміни цитокінового профрілю сироватки крові у щурів за умови пасивного тютюнокуріння на тлі тривалого введення натрію глутамату у віковому аспекті.

Матеріали і методи. Досліди проведено на 64 безпородних білих щурах-самцях, яких поділили на такі групи: перша - контрольна; друга - щури, яким моделювали пасивне тютюнокуріння; третя - тварини, яким вводили натрію глутамат; четверта - щури, яким моделювали пасивне тютюнокуріння на тлі введення натрію глутамату. Визначення вмісту цитокінів сироватки крові проводили методом твердофразового імунофрерментного аналізу з використанням наборів реагентів «RауBio» виі робництва «RayBiotech» (США) відповідно до протоколу виробника на аналізаторі «Multiscan FC» (Фінляндія).

Результати. У статевозрілих щурів пасивне тютюнокуріння на тлі застосування натрію глутамату супроводжувалося вираженим збільшенням вмісту IL1 $\beta$ (у 2,2 раза $(p<0,001))$ відносно контрольної групи, що вірогідно не відрізнялося від аналогічного показника за умови ізольованої дії тютюнового диму. Вміст TNF збільшувався більш виражено (у 2,9 раза $(p<0,001))$ відносно контрольної групи і на $32,3 \%(p<0,002)$ перевищував дані за умови ізольованої дії тютюнового диму. Щодо протизапального цитокіну ILIO, то встановлено його вірогідне зниження на 61,0 \% $(p<0,001)$ відносно контрольної групи, що було на 29,7\% $(p<0,001)$ нижче аналогічного показника за умови ізольованої дії тютюнового диму. У віковому аспекті порушення цитокіно-
The changes of cytokine profile in rats with modeled secondhand tobacco smoking combined with prolonged administration of monosodium glutamate in the age aspect

N. V. Hetsko, I. Ya. Krynytska

I. Horbachevsky Ternopil National Medical University e-mail: nadikage@ukr.net

Summary. The World Health Organization considers tobacco smoke as global health and social problem. The active use of dietary supplements across the whole food industry is ambiguous due to human health and safety. So, the study of molecular mechanisms of toxicity of isolated and combined action of tobacco smoking and monosodium glutamate is one of the topical issues of modern science.

The aim of the study - to determine changes in the cytokine profile of blood serum in rats under secondhand tobacco smoking combined with a long-term monosodium glutamate injection in the age aspect.

Materials and Methods. Experiments were performed on 64 outbred white male rats divided into the following groups: I - control group; II - rats with modeled secondhand tobacco smoking; III - rats, which were injected with monosodium glutamate; IV - rats with modeled secondhand tobacco smoking combined with the monosodium glutamate injection. Blood serum cytokine content was performed by enzyme-linked immunosorbent assay (ELISA) Kit developed by RayBiotech (USA) due to the manufacturer's protocol on a Multiscan FC analyzer (Finland).

Results. We have established a pronounced increase of IL1 $\beta$ (in 2.2-times $(p<0.001)$ ) in mature rats in case of secondhand tobacco smoking combined with monosodium glutamate injection concerning the control group. This did not differ from the same indicator due to the isolated effect of tobacco smoke. TNF $\alpha$ increased more pronouncedly (in 2.9-times $(p<0.001))$ concerning the control group and $32.3 \%(p<0.002)$ exceeded the data due to the isolated effect of tobacco smoke. A pronounced decrease of the anti-inflammatory cytokine IL10 to $61.0 \%$ (p<0.001) concerning the control group was established. This was $29.7 \%(p<0.001)$ below a similar indicator due to the isolated effect of tobacco smoke. In the age aspect, changes in blood serum cytokine profile in immature rats are more pronounced.

Conclusions. Secondhand tobacco smoke combined with monosodium glutamate injection is accompanied by 
вого профілю сироватки крові більш виражено проявилися у статевонезрілих щурів.

Висновки. Пасивне тютюнокуріння на тлі застосування натрію глутамату супроводжується вираженою дисцитокінемією, що підтверджується вірогідним збільшенням вмісту прозапальних цитокінів (TNF $\alpha$ ) на тлі зниження вмісту протизапальних цитокінів (IL10) відносно даних за умови ізольованої дії тютюнового диму. У віковому аспекті за умови пасивного тютюнокуріння на тлі застосування натрію глутамату інтенсивність змін вмісту цитокінів TNF $\alpha$, IL1 $\beta$ ma IL10 у сироватці крові статевонезрілих щурів перевищує показники статевозрілих на 141,9; 70,4 і 16,1% відповідно.

Ключові слова: пасивне тютюнокуріння; натрію глутамат; вік; цитокіни.

\section{ВСТУП}

Всесвітня організація охорони здоров'я розглядає тютюнокуріння як глобальну медико-соціальну проблему. Згідно з оцінками фрахівців, щорічно від хвороб, зумовлених тютюнокурінням, помирає близько 5 млн осіб $[1,2]$. В Україні за даними звіту «Самооцінка населенням стану здоров'я та рівня доступності окремих видів медичної допомоги у 2018 році» (без урахування тимчасово окупованої території Автономної Республіки Крим, м. Севастополя та частини зони проведення антитерористичної операції) у 2018 р. було 5,96 млн курців [3]. Важливою проблемою $є$ і поширеність тютюнокуріння серед підлітків. За даними Глобального опитування дорослих щодо вживання тютюну (GATS 2017), перші експериментування 3 тютюном припадали переважно на вік 12-13 років (11,7 \% респондентів), у 7,5 \% - на вік 10 років, у 6,1 \% - на вік 8-9 років, у 4,6 \% - на вікову групу 7 років і менше. Отже, у віці до 10 років майже кожен десятий підліток в Україні мав першу спробу куріння [4].

Водночас, активне застосування штучних харчових добавок, які знайшли своє широке застосування у сучасній харчовій промисловості, викликає неоднозначне ставлення щодо їх безпеки відносно здоров'я людини $[5,6]$. Найбільш поширеною харчовою добавкою $є$ натрію глутамат [7-9]. В Україні не існує чітких нормативів умісту натрію глутамату в більшості харчових продуктів. Водночас, деякі дослідники зазначають, що застосування натрію глутамату навіть у низьких дозах (0,3-1 г на добу) $\epsilon$ токсичним $[10,11]$. Реальна загроза одночасного надходження в організм тютюнового диму та натрію глутамату надає вивченню їхньої поєднаної дії особливої актуальності.

Універсальним механізмом, що відіграє ключову роль у реалізації дії більшості токсичних агентів, $€$ активація вільнорадикальних процесів та розвиток оксидативного стресу [12]. Встановлено, що ізольована дія тютюнового диму та натрію глутамату в дозі 30 мг/кг зумовлює вірогідні зміни проо- more pronounced dyscytokinemia. It was confirmed by the probable increase of proinflammatory cytokines (TNF $\alpha$ ) combined with the decrease of anti-inflammatory cytokines (IL10) compared to the data under the isolated action of tobacco smoke. In the age aspect under passive tobacco smoking combined with monosodium glutamate injection, intensive changes in the cytokines TNF $\alpha$, $I L 1 \beta$ and IL10 in the blood serum of immature rats exceed indexes of mature on 141.9; 70.4 and $16.1 \%$, respectively.

Key words: secondhand tobacco smoke; monosodium glutamate; age; cytokines.

ксидантно-антиоксидантної рівноваги у щурів, а їх поєднання викликає більш суттєві порушення, ніж при дії кожного з них окремо $[13,14] . \in$ дані, що оксидативний стрес може бути промотором активації системи прозапальних цитокінів $[15,16]$.

Метою дослідження було вивчити зміни цитокінового профрілю сироватки крові у щурів за умови пасивного тютюнокуріння на тлі тривалого введення натрію глутамату у віковому аспекті.

\section{МАТЕРІАЛИ I МЕТОДИ}

Досліди виконані на 32 безпородних статевозрілих білих щурах-самцях масою 180-200 г та 32 безпородних статевонезрілих білих щурах-самцях масою 60-80 г, яких у поділили на чотири підгрупи: перша - контрольна (n=8); друга - щури, яким моделювали пасивне тютюнокуріння (n=8); третя - тварини, яким вводили натрію глутамат (n=8); четверта - щури, яким моделювали пасивне тютюнокуріння на тлі введення глутамату натрію $(n=8)$.

Вплив тютюнового диму (пасивне тютюнокуріння) моделювали шляхом поміщення щурів у спеціально сконструйовану камеру 3 оргскла об'ємом 30 л, що дозволило обкурювати тварин у вільній поведінці. Задимлення проводили шляхом спалювання двох цигарок «Прима срібна (червона)» (смоли - 10 мг/циг., нікотин - 0,8 мг/циг.). У камері одночасно перебували 4 тварини. Дослідні щури проходили процедуру пасивного тютюнокуріння 2 рази на добу по 30 хв. Після закінчення кожного 30-хвилинного сеансу тварин витягали 3 камери і поміщали в стандартну клітку віварію. Тривалість експерименту становила 30 діб $[17,18]$.

щурам другої дослідної групи протягом 30-ти діб внутрішньошлунково вводили натрію глутамат у дозі 30 мг/кг, розчинений у 0,5 мл дистильованої води кімнатної температури [19]. Щурам третьої дослідної групи моделювали пасивне тютюнокуріння і вводили натрію глутамат протягом 30-ти діб. Контрольною була група інтактних тварин. 
Усі маніпуляції з експериментальними тваринами проводили із дотриманням правил відповідно до Європейської конвенції про захист хребетних тварин, що використовуються для дослідних та інших наукових цілей (Страсбург, 1986) [20].

Визначення вмісту цитокінів сироватки крові проводили методом твердофразового імуноферментного аналізу з використанням наборів реагентів «RayBio» виробництва «RayBiotech» (США) відповідно до протоколу виробника на аналізаторі «Multiscan FC» (Фінляндія) та виражали у пг/мл.

Статистичну обробку цифрових даних здійснювали за допомогою програмного забезпечення Excel (Microsoft, США) та STATISTICA 6.0 (Statsoft, США). Зважаючи на непараметричний розподіл кількісних характеристик, дані представляли у вигляді медіани та квартилів (нижнього та верхнього) - Me (Lq; Uq). Порівняльний аналіз чотирьох груп здійснювали 3 використанням непараметричного критерію Краскела-Уолліса. При отриманні його вірогідних значень $(\mathrm{p}<0,05)$ подальше попарне порівняння груп проводили 3 використанням критерію Манна-Уїтні з урахуванням поправки Бонферроні при оцінці значень р.

\section{РЕЗУЛЬТАТИ ТА ОБГОВОРЕННЯ}

При порівнянні показників цитокінового профрілю сироватки крові у статевозрілих та статевонез- рілих щурів-самців контрольної групи встановлено більш високі значення у статевозрілих щурів - вірогідне переважання вмісту IL1ß на 49,9 \%, TNF $\alpha$ - на 32,8 \%, IL10 - на 41,6 \% (рис. 1).

Вміст IL1ß у сироватці крові статевозрілих самців за умови пасивного тютюнокуріння вірогідно збільшився на 96,5 \% відносно контрольної групи (табл. 1). Пасивне тютюнокуріння на тлі застосування натрію глутамату супроводжувалося більш вираженим збільшенням даного показника (у 2,2 раза $(p<0,001))$ відносно контрольної групи, проте Bміст IL1 $\beta$ при цьому вірогідно не перевищував да-

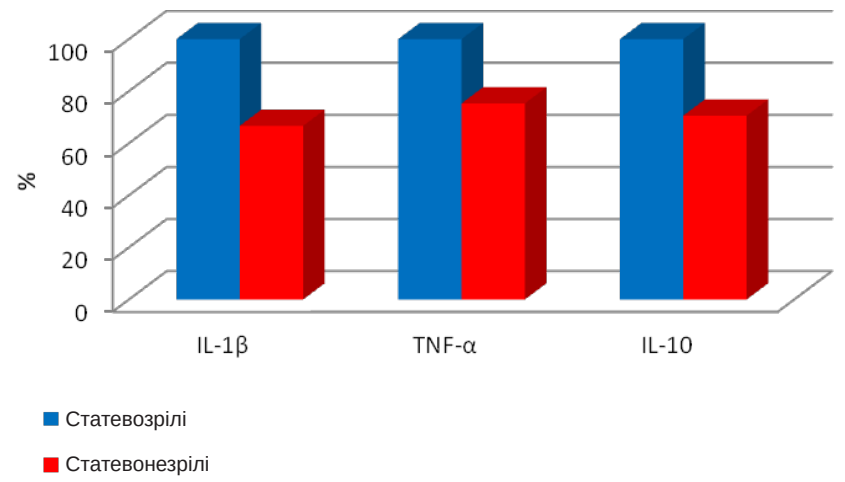

Рис. 1. Зівставлення вмісту IL1 $\beta$, TNF $\alpha$ та IL10 у сироватці крові статевозрілих та статевонезрілих щурів контрольної групи у відсотках.

Таблиця 1. Вплив тютюнового диму і натрію глутамату на цитокіновий профріль у сироватці крові статевозрілих щурів $\left(\mathrm{Me}\left[\mathrm{Q}_{25}-\mathrm{Q}_{75}\right]\right)$

\begin{tabular}{|c|c|c|c|c|}
\hline \multirow[t]{2}{*}{ Показник } & \multicolumn{4}{|c|}{ Група тварин } \\
\hline & контрольна & $\begin{array}{l}\text { друга (пасивне } \\
\text { тютюнокуріння) }\end{array}$ & $\begin{array}{l}\text { третя (натрію } \\
\text { глутамат) }\end{array}$ & $\begin{array}{c}\text { четверта (пасивне тютюнокуріння } \\
+ \text { натрію глутамат) }\end{array}$ \\
\hline IL1ß, пг/мл & $\begin{array}{c}8,50 \\
(8,10 ; 10,75)\end{array}$ & $\begin{array}{c}16,70 \\
(14,07 ; 17,82) \\
p_{1-2}<0,001^{*}\end{array}$ & $\begin{array}{c}12,18 \\
(10,59 ; 14,39) \\
p_{1-3}=0,016 \\
p_{2-3}=0,009\end{array}$ & $\begin{array}{c}18,45 \\
(17,01 ; 19,53) \\
\mathrm{p}_{1-4}<0,001^{*} \\
\mathrm{p}_{2-4}>0,05 \\
\mathrm{p}_{3-4}<0,001^{\star}\end{array}$ \\
\hline \multicolumn{5}{|c|}{ Критерій Краскела-Уолліса, p (H=26,18; p<0,001*) } \\
\hline TNFa, пг/мл & $\begin{array}{c}5,38 \\
(4,11 ; 6,11)\end{array}$ & $\begin{array}{c}11,75 \\
(11,25 ; 12,65) \\
p_{1-2}<0,001^{*}\end{array}$ & $\begin{array}{c}8,15 \\
(7,59 ; 8,52) \\
\mathrm{p}_{1-3}<0,001^{*} \\
\mathrm{p}_{2-3}<0,002^{\star}\end{array}$ & $\begin{array}{c}15,55 \\
(14,95 ; 16,65) \\
\mathrm{p}_{1-4}<0,001^{\star} \\
\mathrm{p}_{2-4}<0,002^{\star} \\
\mathrm{p}_{3-4}<0,001^{\star}\end{array}$ \\
\hline \multicolumn{5}{|c|}{ Критерій Краскела-Уолліса, p $(28,75 ;$ p<0,001*) } \\
\hline IL10, пг/мл & $\begin{array}{c}17,70 \\
(15,55 ; 18,35)\end{array}$ & $\begin{array}{c}9,81 \\
(9,07 ; 11,06) \\
p_{1-2}<0,001^{*}\end{array}$ & $\begin{array}{c}14,15 \\
(13,75 ; 15,00) \\
p_{1-3}=0,036 \\
p_{2-3}<0,001^{*}\end{array}$ & $\begin{array}{l}\quad 6,90 \\
(6,76 ; 7,70) \\
\mathrm{p}_{1-4}<0,001^{*} \\
\mathrm{p}_{2-4}<0,001^{*} \\
\mathrm{p}_{3-4}<0,001^{*}\end{array}$ \\
\hline
\end{tabular}

Критерій Краскела-Уолліса, $\mathrm{p}\left(\mathrm{H}=27,33 ; \mathrm{p}<0,001^{*}\right)$

Примітки: 1) $\mathrm{p}_{1-2}, \mathrm{p}_{1-3}, \mathrm{p}_{1-4}$ - вірогідність відмінностей між контрольною групою і дослідними групами; $\mathrm{p}_{2-3}, \mathrm{p}_{2-4}-$ вірогідність відмінностей між групою 3 тютюнокурінням і групою з введенням натрію глутамату та групою із тютюнокурінням на тлі введення натрію глутамату;

$\mathrm{p}_{3-4}$ - вірогідність відмінностей між групою з введенням натрію глутамату і групою з тютюнокурінням на тлі введення натрію глутамату; рівень вірогідності при попарному порівнянні груп для критерію Манна-Уїтні згідно з поправкою Бонферроні, р<0,008;

2) * - статистично значущі результати. 
ний показник за умови ізольованої дії тютюнового диму та на 51,5 \% (р<0,001), а перевищував даний показник за умови тривалого введення натрію глутамату. При цьому ізольоване введення натрію глутамату зумовило підвищення вмісту IL1ß у сироватці крові на 43,3 \%, порівняно 3 групою контрольною, проте ці дані виявилися статистично невірогідними ( $p=0,016)$.

У сироватці крові статевонезрілих самців вміст IL1ß за умови пасивного тютюнокуріння вірогідно збільшився у 2,3 раза відносно контрольної групи (табл. 2). Пасивне тютюнокуріння на тлі застосування натрію глутамату супроводжувалося більш вираженим збільшенням даного показника (у 2,9 раза $(p<0,001))$ відносно контрольної групи. Варто вказати, що отримані дані на 23,0 \% (p<0,001) перевищували вміст IL1ß за умови ізольованої дії тютюнового диму та на 55,2 \% ( $<<0,001)$ - дані за умови тривалого введення натрію глутамату. При цьому ізольоване введення натрію глутамату зумовило вірогідне підвищення вмісту IL1 $\beta$ у сироватці крові на 85,2 \% порівняно з даними контрольних щурів.

У віковому аспекті інтенсивність змін вмісту IL1ß у сироватці крові перевищувала показники статевозрілих самців за умови пасивного тютюнокуріння - на 37,2 \%, за умови тривалого введення натрію глутамату - на 41,9 \%, за умови пасивного тютюнокуріння на тлі натрію глутамату - на 70,4 \% відповідно.

Уміст TNFa у сироватці крові статевозрілих самців за умови пасивного тютюнокуріння вірогідно збільшився у 2,2 раза відносно контрольної групи. Пасивне тютюнокуріння на тлі застосування натрію глутамату супроводжувалося більш вираженим збільшенням даного показника (у 2,9 раза $(p<0,001))$ відносно контрольної групи. При цьому вміст TNFa вірогідно перевищував даний показник за умови ізольованої дії тютюнового диму на $32,3 \%(p<0,002)$ та на 90,8 \% ( $p<0,001)$ перевищував даний показник за умови тривалого введення натрію глутамату. Варто вказати, що ізольоване введення натрію глутамату зумовило вірогідне підвищення вмісту TNFa у сироватці крові на 51,5 \% порівняно з групою контролю.

У сироватці крові статевонезрілих самців уміст TNFa за умови пасивного тютюнокуріння вірогідно збільшився у 3,1 раза відносно контрольної групи. Пасивне тютюнокуріння на тлі застосування натрію глутамату супроводжувалося більш вираженим збільшенням даного показника (у 4,3 раза $(p<0,001))$ відносно контрольної групи, що на 39,6 \% $(p<0,003)$ більше даного показника за умови ізольованої дії тютюнового диму та у 2,1 раза $(p<0,001)$ більше даного показника за умови тривалого введення натрію глутамату. При цьому ізо-

Таблиця 2. Вплив тютюнового диму і натрію глутамату на цитокіновий профіль у сироватці крові статевонезрілих щурів $\left(\mathrm{Me}\left[\mathrm{Q}_{25}-\mathrm{Q}_{75}\right]\right)$

\begin{tabular}{|c|c|c|c|c|}
\hline \multirow[b]{2}{*}{ Показник } & \multicolumn{4}{|c|}{ Група тварин } \\
\hline & контрольна & $\begin{array}{l}\text { друга (пасивне } \\
\text { тютюнокуріння) }\end{array}$ & третя (натрію глутамат) & $\begin{array}{c}\text { четверта (пасивне тютюнокуріння } \\
+ \text { натрію глутамат) } \\
\end{array}$ \\
\hline IL1ß, пг/мл & $\begin{array}{c}5,67 \# \\
(5,30 ; 6,24)\end{array}$ & $\begin{array}{c}13,25 \# \\
(12,60 ; 13,50) \\
p_{1-2}<0,001^{*}\end{array}$ & $\begin{array}{c}10,50 \# \\
(8,74 ; 11,45) \\
\mathrm{p}_{1-3}<0,001^{*} \\
\mathrm{p}_{2-3}<0,001^{*}\end{array}$ & $\begin{array}{c}16,30 \# \\
(15,95 ; 16,60) \\
\mathrm{p}_{1-4}<0,001^{*} \\
\mathrm{p}_{2-4}<0,001^{*} \\
\mathrm{p}_{3-4}<0,001^{*} \\
\end{array}$ \\
\hline \multicolumn{5}{|c|}{ Критерій Краскела-Уолліса, p (H=29,01; p<0,001*) } \\
\hline TNFa, пг/мл & $\begin{array}{c}4,05 \# \\
(3,92 ; 4,70)\end{array}$ & $\begin{array}{c}12,50 \\
(11,05 ; 13,94) \\
p_{1-2}<0,001^{*}\end{array}$ & $\begin{array}{c}8,45 \\
(8,13 ; 9,23) \\
\mathrm{p}_{1-3}<0,001^{*} \\
\mathrm{p}_{2-3}<0,003^{\star}\end{array}$ & $\begin{array}{c}17,45 \\
(15,33 ; 18,52) \\
\mathrm{p}_{1-4}<0,001^{\star} \\
\mathrm{p}_{2-4}<0,003^{\star} \\
\mathrm{p}_{3-4}<0,001^{\star} \\
\end{array}$ \\
\hline \multicolumn{5}{|c|}{ Критерій Краскела-Уолліса, p (28,60; p<0,001*) } \\
\hline IL10, пг/мл & $\begin{array}{c}12,50 \# \\
(10,77 ; 13,95)\end{array}$ & $\begin{array}{c}5,76 \# \\
(5,21 ; 6,12) \\
p_{1-2}<0,001^{*}\end{array}$ & $\begin{array}{c}8,86 \# \\
(8,11 ; 9,21) \\
\mathrm{p}_{1-3}<0,001^{*} \\
\mathrm{p}_{2-3}<0,001^{\star}\end{array}$ & $\begin{array}{l}2,86 \# \\
(2,50 ; 3,49) \\
\mathrm{p}_{1-4}<0,001^{*} \\
\mathrm{p}_{2-4}<0,001^{*} \\
\mathrm{p}_{3-4}<0,001^{*}\end{array}$ \\
\hline \multicolumn{5}{|c|}{ Критерій Краскела-Уолліса, p (H=28,91; p<0,001*) } \\
\hline
\end{tabular}

Примітки: 1) $\mathrm{p}_{1-2,} \mathrm{p}_{1-3,} \mathrm{p}_{1-4}$ - вірогідність відмінностей між контрольною групою і дослідними групами; $\mathrm{p}_{2-3}, \mathrm{p}_{2-4}-$ вірогідність відмінностей між групою 3 тютюнокурінням і групою з введенням натрій глутамату та групою із тютюнокурінням на тлі введення натрію глутамату; $p_{3-4}-$ вірогідність відмінностей між групою з введенням натрію глутамату і групою з тютюнокурінням на тлі введення натрію глутамату; рівень вірогідності при попарному порівнянні груп для критерію Манна-Уїтні згідно з поправкою Бонферроні, p<0,008;

2) * - статистично значущі результати. 
льоване введення натрію глутамату зумовило вірогідне підвищення вмісту TNFa у сироватці крові в 2,1 раза порівняно з даними контрольних щурів.

У віковому аспекті інтенсивність змін вмісту TNF $\alpha$ у сироватці крові перевищувала показники статевозрілих самців за умови пасивного тютюнокуріння - на 90,2 \%, за умови тривалого введення натрію глутамату - на 57,1 \%, за умови пасивного тютюнокуріння на тлі натрію глутамату - на 141,9 \% відповідно.

Уміст IL10 у сироватці крові статевозрілих самців за умови пасивного тютюнокуріння вірогідно зменшився на 44,6 \% відносно контрольної групи. Пасивне тютюнокуріння на тлі застосування натрію глутамату супроводжувалося більш вираженим зниженням даного показника (на 61,0 \% (р<0,001)) відносно контрольної групи, що на 29,7 \% $(p<0,001)$ менше даного показника за умови ізольованої дії тютюнового диму та на 51,2 \% ( $<<0,001)$ менше даного показника за умови тривалого введення натрію глутамату. При цьому ізольоване введення натрію глутамату не зумовило вірогідного зниження вмісту IL10 у сироватці крові порівняно з даними контрольних щурів.

У статевонезрілих самців за умови пасивного тютюнокуріння вміст IL10 у сироватці крові вірогідно зменшився на 53,9 \% відносно контрольної групи. Пасивне тютюнокуріння на тлі застосування натрію глутамату супроводжується більш вираженим зниженням даного показника (на 77,1 \% (р<0,001)) відносно контрольної групи, що на 50,3 \% $(p<0,001)$ нижче даного показника за умови ізольованої дії тютюнового диму та на 67,7 \% ( $p<0,001)$ менше даного показника за умови тривалого введення натрію глутамату. При цьому ізольоване введення натрію глутамату зумовило вірогідне зниження вмісту IL10 у сироватці крові на 29,1\% порівняно з даними контрольних щурів.

У віковому аспекті інтенсивність змін вмісту IL10 у сироватці крові перевищувала показники статевозрілих самців за умови пасивного тютюнокуріння - на 9,3 \%, за умови тривалого введення натрію глутамату - на 9,0 \%, за умови пасивного тютюнокуріння на тлі натрію глутамату - на 16,1% відповідно.

Результати наших досліджень співзвучні із даними інших дослідників. Так, П. Г. Лихацький та Л. С. Фіра провели дослідження на білих безпородних щурах-самцях різного віку, яких щоденно протягом 45 діб піддавали дії тютюнового диму в герметичній камері (час експозиції 6 хв). Встановлено, що ураження щурів тютюновим димом призвело до збільшення у сироватці крові вмісту прозапального цитокіну IL6. Найчутливішими до даного токсиканта виявились статевонезрілі щури, у яких вміст IL6 зростав на 50 \%, 164 та 237 \% відповідно через 15; 30 та 45 діб після ураження [21].
В. Д. Орлова та О. А. Хренов у пацієнтів хронічною легеневою недостатністю та хронічною серцевою недостатністю зі стажем куріння більше 10 років встановили підвищений ліпополісахарид-індукований синтез мононуклеарними лейкоцитами прозапальних цитокінів (TNFa, IL1ß) [22].

Н. М. Ненашева також зазначає, що тютюновий дим стимулює вивільнення прозапальних медіаторів, таких, як IL8, IL6, лейкотрієн-B , проста-

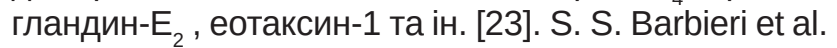
спостерігали підвищення умісту прозапальних цитокінів TNF $\alpha$, IL1 $\beta$ у сироватці крові курців відносно осіб, які не курять [24]. K. Hart et al. встановили, що конденсат тютюнового диму або бензапірен індукують активацію промотора гена IL1 $\beta$, що проявляє специфрічний поліморфізм-31Т/С в епітеліальних клітинах легень людини [25], a L. Hou et al. виявивши, що у курців поліморфізм гена TNFa (-806C>T) асоціювався із гострим інфарктом міокарда, припустили наявність вірогідних взаємодій між генами IL1ß та TNFa і курінням [26].

Відомо, що тютюновий дим містить більше 5 тис. компонентів, серед яких канцерогени, токсини, оксиданти, і т.д. Загалом, за даними Д. Г. Янбаєвої та співавт. тютюновий дим містить $10^{17}$ молекул оксидантів на один вдих [27]. Впливаючи на епітелій бронхів і альвеоли, тютюновий дим викликає вивільнення цитокінів і хемокінів з альвеолярних макрофагів, епітеліальних клітин, що зумовлює міграцію із циркуляторного русла нейтрофілів, макрофагів, дендритних клітин, природних кілерів, які, у свою чергу, також виробляють цитокіни [28]. При цьому синтез цитокінів безпосередньо залежить і від окисно-відновлювального потенціалу клітин-продуцентів цитокінів [29].

Ймовірно, що введення натрію глутамату підсилює прооксидний ефект тютюнового диму через збільшення генерації активних фрорм оксигену (АФО) у дихальному ланцюзі мітохондрій, чим зумовлює розвиток більш вираженого оксидативного стресу та більш інтенсивний синтез прозапальних цитокінів за умови поєднаної дії дослідних чинників відносно ізольованої дії тютюнового диму. Крім того $€$ дані, що натрію глутамат здатний чинити модуляторний вплив на фрункції циркулюючих фрагоцитів як при застосуванні in vivo, так і в умовах in vitro [30] із подальшою їх прозапальною метаболічною активацією. Гранулоцити та моноцити із прозапальним профілем характеризуються підвищеним рівнем прозапальних цитокінів та хемокінів, а також посиленням продукції АФО, які також є потужними прозапальними медіаторами і сигнальними молекулами [31].

Зв'язок між прозапальними цитокінами й оксидативним стресом проявляється у розвитку запальної відповіді. Прозапальні цитокіни та оксидативний стрес мають спільні шляхи передачі сигналів, які зумовлюють посилення запального 
каскаду в основному через активацію мітогенактивованої протеїнкінази (МАРК) і нуклеарного фрактора карра B (NF-кB). Димери NF-кB містяться у цитоплазмі клітини в неактивній фрормі, зв'язані 3 інгібуючим протеїном ІкВ. Фосфрорилування ІкВ так званим IKK (IкB kinase)-комплексом у відповідь на різні стимули зумовлює їх протеолітичне розщеплення та активацію NF-kB, який потім переміщається в ядро клітини, де зв'язується 3 промоторною ділянкою специфрічного гена і запускає процес транскрипції [32-34]. Багато ефректорних генів, у тому числі й ті, що кодують цитокіни і молекули адгезії, регулюються за допомогою NF-кB. $€$ дані, що глутамат спричиняє швидке зниження рівня інгібіторного протеїну ІкВ і нуклеарну транслокацію субодиниці NF-кB - p65, що безпосередньо залучена у IL1- та TNF $\alpha$-залежну стимуляцію моноцитарних запальних генів [35].

Крім того прозапальні цитокіни, у тому числі TNFa, й оксидативний стрес сприяють один одному в генерації хибного кола за умови запалення. Так само було виявлено і зворотну взаємодію

\section{СПИСОК ЛІТЕРАТУРИ}

1. Jha P. Global hazards of tobacco and the benefits of smoking cessation and tobacco taxes / P. Jha, M. MacLennan, F. J. Chaloupka [et al.] // Disease Control Priorities. The World Bank. - 2015. - No. 3. - P. 175-194.

2. World Health Organization. WHO report on the global tobacco epidemic, 2019: https://apps.who.int/iris/bitstream/ handle/10665/326043/9789241516204-eng.pdf?ua=1

3. Komitet statystyky Ukrayiny D. Samootsinka efektyvnoho stanu zdorov'ya ta dostupnosti zrostala medychnoyi dopomohy u 2008 rotsi [Elektronic resource]. Access mode : http: // www. ukrstat. gov. ua \operativ2009. html.

4. Глобальне опитування дорослих щодо вживання тютюну (Global Adult Tobacco Survey - GATS) (англ. мова). - К., 2017. - С. 240.

5. Волков І. І. Глутамат натрію як харчова добавка і її вплив на здоров'я / І. І. Волков, О. Ю. Косілова, Н. М. Кателевська // Scientific discoveries: projects, strategies and development: Collection of scientific papers « $\wedge$ 'ОГО $\Sigma »$ with Proceedings of the International Scientific and Practical Conference (Vol. 2), October 25, 2019. Edinburgh, UK: European Scientific Platform. - C. 38-40.

6. Potential effects of umami ingredients on human health: Pros and cons / Y. Zhang, L. Zhang, C. Venkitasamy [et al.] // Critical Reviews in Food Science and Nutrition. 2019. - Vol. 4. - P. 1-9.

7. Bhattacharya T. Effect of neonatal exposure of monosodium glutamate in kidney of albino mice - a histological study / T. Bhattacharya, S. K. Ghosh // Nepal Med. Coll. J. - 2019. - Vol. 21(2). - P. 134-141.

8. Application of glutamate-sensitive biosensor for analysis of foodstuff / D. Yu. Kucherenko, I. S. Kucherenko, O. O. Soldatkin, A. P. Soldatkin // Biotechnologia Acta. 2018. - Vol. 11 No. 4. - P. 57-67.

9. Monosodium glutamate (MSG)-induced male

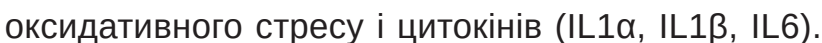
Так, блокування сигнального шляху інтерлейкіну-1 приводило до зниження рівня оксидативного стресу та інших прозапальних цитокінів. Тобто існує хибне коло, в якому оксидативний стрес зумовлює підвищення кількості прозапальних цитокінів, а вони, у свою чергу, посилюють оксидативний стрес [16].

\section{ВИСНОВКИ}

Пасивне тютюнокуріння на тлі застосування натрію глутамату супроводжується вираженою дисцитокінемією, що підтверджується вірогідним збільшенням вмісту прозапальних цитокінів (TNF $\alpha$ ) на тлі зниження умісту протизапальних цитокінів (IL10) відносно даних за умови ізольованої дії тютюнового диму. У віковому аспекті за умови пасивного тютюнокуріння на тлі застосування натрію глутамату інтенсивність змін вмісту цитокінів TNFa, IL1ß та IL10 у сироватці крові статевонезрілих щурів перевищує показники статевозрілих на 141,9;70,4 і 16,1 \% відповідно.

reproductive dysfunction: A mini review / O. T. Kayode, D. E. Rotimi, A. A. Kayode // Toxics. - 2020. - Vol. 8(1). - P. 7.

10. Effect of monosodium glutamate on behavioural phenotypes, biomarkers of oxidative stress in brain tissues and liver enzymes in mice / U. Solomon, O. O. Gabriel, E. O. Henry [et al.] // World J. Neurosel. - 2015. - No. 5. - P. 339-349.

11. Tawfik M. S. Adverse effects of monosodium glutamate on liver and kidney functions in adult rats and potential protective effect of vitamins $\mathrm{C}$ and $\mathrm{E} /$ M.S. Tawfik, N.Al-Badr//FoodandNutritionSciences.-2012.Vol. 3. - P. 651-659.

12. Xenobiotics, oxidative stress, and antioxidants / F. M. El-Demerdash, E. M. Tousson, J. Kurzepa, S. L. Habib // Oxidative Medicine and Cellular Longevity. - 2018. Vol. 2018. - P. 1- 2.

13. Руцька А. В. Показники вільнорадикального окиснення в щурів за умови «пасивного тютюнокуріння» на тлі тривалого введення глутамату натрію у статевому і віковому аспектах / А. В. Руцька, І. Я. Криницька, М. І. Марущак // Медична та клінічна хімія. - 2017. T. 19, № 4(73). - С. 115-122.

14. Руцька А. В. Дослідження ензимної ланки антиоксидантної системи у щурів за умови дії тютюнового диму на тлі застосування натрій глутамату у статевому та віковому аспектах / А. В. Руцька // Медична та клінічна хімія. - 2018. - Т. 20, № 3(76). - С. 145-153.

15. Ащеулова Т. В. Взаимосвязь иммунной активации и оксидативного стресса при прогрессировании артериальной гипертензии / Т. В. Ащеулова, М. В. Заика, Н. Н. Герасимчук // Український терапевтичний журнал. - 2007. - № 2. - С. 12-16.

16. Аль-Акрас Р. К. М. Влияние окислительного стресса на уровень цитокинов в культуре клеток / Р. К. М. Аль-Акрас // Международный научно-исследовательский журнал. - 2014. - №4 (23). - С. 78-80. 
17. Лизурчик Л. В. Влияние табачного дыма на содержание токсичных элементов в организме крыс / Л. В. Лизурчик, Е. В Шейда // Вестн. ОГУ. - 2014. № 6(167). - C. 71-74.

18. Exposure to secondhand smoke impairs fracture healing in rats / H. A. Santiago, A. Zamarioli, M. D. Sousa Neto, J. B. Volpon // Clin. Orthop. Relat. Res. - 2017. Vol. 475(3). - P. 894-902.

19. Влияние глипролинов на структурно-фрункциональное состояние слизистой оболочки желудка и массу тела крыс в условиях длительного введения глутамата натрия / [Т. М. Фалалеева, Г. Е. Самонина, Т. В. Береговая и др.] // Фізика живого. - 2010. - Т. 18, №1. - C. 154-159.

20. European convention for the protection of vertebrate animals used for experimental and other scientific purposes: Council of Europe. Strasbourg. - 1986. - No. 123. - P. 1-11.

21. Лихацький П. Г. Розвиток нітрооксидативного стресу та запальних процесів у щурів різного віку, уражених тютюновим димом / П. Г. Лихацький, Л. С. Фіра // Світ медицини та біології. - 2017. - № 4(62). - С. 145-149.

22. Орлова В. Д. Вплив тривалого стажу тютюнопаління на LPS-індукований синтез прозапальних цитокінів TNF-A i IL-1B мононуклеарними лейкоцитами у хворих із хронічною легеневою і хронічною серцевою недостатністю / В. Д. Орлова, О. А. Хренов // Здобутки клінічної і експериментальної медицини. - 2012. - № 1. - С. 108- 110.

23. Ненашева Н. М. Бронхиальная астма и курение / Н. М. Ненашева // Эфрфективная фрармакотерапия. 2013. - № 10. - C. 4-12.

24. Cytokines present in smokers' serum interact with smoke components to enhance endothelial dysfunction / S. S. Barbieri, E. Zacchi, P. Amadio [et al.] // Cardiovascular Research. - 2011. - Vol. 90. - P. 475-483.

25. Hart K. Allele-specific induction of IL1B -31T/C promoter polymorphism by lung carcinogens / K. Hart, A. Haugen, S. Zienolddiny // Mutat Res. - 2008. - Vol. 656. P. 14-18.

\section{REFERENCES}

1. Jha $P$, MacLennan $M$, Chaloupka FJ, Yurekli $A$, Ramasundarahettige C, Palipudi K, Zatońksi W, et al. Global hazards of tobacco and the benefits of smoking cessation and tobacco taxes. Disease Control Priorities. The World Bank. 2015;3: 175-94.

2. World Health Organization. WHO report on the global tobacco epidemic 2019: Offer help to quit tobacco use.

3. Statistics Committee of Ukraine. Self-assessment of effective health and affordability of health care growth in 2008 [Electronic resource]. Available from: http: // www. ukrstat. gov. ua \operativ2009. html. Ukrainian.

4. [Global survey of adults on tobacco use] (Global Adult Tobacco Survey - GATS) (English). Kyiv; 2017. Ukrainian.

5. Katelevska NM, Kosilova OYu, Volkov II. [Sodium glutamate as a dietary supplement and its health effects]. Doctor's thesis. European Scientific Platform. 2019;2: 38-9. Ukrainian.

6. Zhang Y, Zhang L, Venkitasamy C, Pan Z, Ke H, Guo S, Wu D, Wu W, Zhao L. Potential effects of umami ingre-
26. Polymorphisms of tumor necrosis factor alpha gene and coronary heart disease in a Chinese Han population: interaction with cigarette smoking / L. Hou, J. Huang, X. Lu [et al.] // Thromb. Res. - 2009. - Vol. 123. - P. 822-826.

27. Systemic effects of smoking. / D. G. Yanbaeva, M. A. Dentener, E. C. Creutzberg [et al.] // Chest. - 2007. Vol. 131 (5). - P. 1557-1566.

28. Ассрандиярова Н. С. Никотин и система иммунитета / Н. С. Асорандиярова // Иммунопатология, аллергология, инфектология. - 2018. - № 3. - С. 6-12.

29. Асмолов О. К. Вплив тютюнопаління на патогенез хронічних обструктивних захворювань легень / [О. К. Асмолов, Т. А. Рибак, І. М. Смольська та ін.] // Одеський медичний журнал. - 2008. - № 6(110). - С. 70-72.

30. Модуляторні ефекти глутамату натрію на фрункції циркулюючих фрагоцитарних клітин щурів in vivo та in vitro / [М. П. Рудик, В. В. Позур, Є. В. Опейда та ін.]// Допов. Нац. акад. наук Укр. - 2017. - № 5. - С. 89-97.

31. Shapiro H. Macrophages, meta-inflammation, and immuno-metabolism / H. Shapiro, A Lutaty, A. Ariel // Scie ntific World J. - 2011. - 11. - P. 2509-2529.

32. Головач И. Ю. Ядерный фрактор кВ (NF-кB) как важный патогенетический фрактор и новая мишень в лечении ревматических заболеваний / И. Ю. Головач // Раціональна фрармакотерапія. - 2012. - № 3(24). - С. 46-51.

33. Effect of glutamate on inflammatory responses of intestine and brain after focal cerebral ischemia / L. Xu, J. Sun, R. Lu, Q. Ji, J.G. Xu. // World J. Gastroenterol. 2005. - No. 11 (5). - P. 733-736.

34. Toxoplasma gondii tachyzoites inhibit proinflammatory cytokine induction in infected macrophages by preventing nuclear translocation of the transcription factor NF-kappa B. J / B. A. Butcher, L. Kim, P. F. Johnson, E. Y. Denkers // Immunol. - 2001. - 167. - P. 2193-2201.

35. Glutamate activates NF-kappaB through calpain in neurons / M. N. Scholzke, I. Potrovita, S. Subramaniam [et al.] // Eur. J. Neurosci. - 2003. - Vol. 18. - P. 3305-3310.

dients on human health: Pros and cons. Critical Reviews in Food Science and Nutrition. 2019;4: 9-1.

7. Bhattacharya T, Ghosh SK. Effect of neonatal exposure of Monosodium Glutamate in kidney of albino mice-a Histological study. Nepal Medical College Journal. 2019;21(2): 134-41.

8. Kucherenko DY, Kucherenko IS, Soldatkin OO, Soldatkin AP. Application of glutamate-sensitive biosensor for analysis of foodstuff. Biotechnologia Acta. 2018;11(4): 5767.

9. Kayode OT, Rotimi DE, Kayode AA, Olaolu TD, Adeyemi OS. Monosodium glutamate (MSG)-induced male reproductive dysfunction: A mini review. Toxics. 2020;8(1): 7.

10. Umukoro S, Oluwole GO, Olamijowon HE, Omogbiya Al, Eduviere AT. Effect of monosodium glutamate on behavioral phenotypes, biomarkers of oxidative stress in brain tissues and liver enzymes in mice. World Journal of Neuroscience. 2015;5: 339-49.

11. Manal Said T, Nawal AB. Adverse effects of monosodium glutamate on liver and kidney functions in adult rats 
and potential protective effect of vitamins C and E. Food and Nutrition Sciences. 2012;3: 651-9.

12. El-Demerdash FM, Tousson EM, Kurzepa J, Habib SL. Xenobiotics, oxidative stress, and antioxidants. Oxidative Medicine and Cellular Longevity. 2018; 2018: 1-2.

13. Rutska AV, Krynytska IY, Marushchak MI. [Indicators of free radical oxidation in rats under the condition of "passive smoking" against the background of long-term introduction of monosodium glutamate in sexual and age aspects]. Med i kiln khim. 2017;19(4): 115-22. Ukrainian.

14. Rutska AV. [Investigation of the enzyme link of the antioxidant system in rats under the influence of tobacco smoke on the background of the use of monosodium glutamate in sexual and age aspects]. Med i kiln khim. 2018;13(3): 145-53. Ukrainian.

15. Ashcheulova TV, Zaika MV, Gerasimchuk NN. [The relationship of immune activation and oxidative stress with the progression of arterial hypertension]. Ukr terap zhurn. 2007;2: 16-2. Ukrainian.

16. Ak-Akras R.K.M. The effect of oxidative stress on the level of cytokines in cell culture. Mezhdunar. nauchislled zhurn. 2014;4(23): 78-80. Russian.

17. Lizurchik LV, Sheida EV. [The effect of oxidative stress on the level of cytokines in cell culture]. Vestn. OGU. 2014;6(167): 71-4. Russian.

18. Santiago HA, Zamarioli A, Neto MD, Volpon JB. Exposure to secondhand smoke impairs fracture healing in rats. Clinical Orthopaedics and Related Research. 2017;475(3): 894-902.

19. Falaleyeva TM, Samonina GE, Beregovaya TV, Dzyubenko NV, Andreyeva LA. [The effect of glyprolins on the structural - functional state of the gastric mucosa and rat body weight under conditions of prolonged administration of sodium glutamate]. Fizika zhivogo. 2010;18(1): 1549. Russian.

20. d'Europa C. European Convention for the protection of Vertebrate Animal Used for experimental and other Scientific Purposes. 1986;123: 1-11.

21. Lykhatskyy PH, Fira LS. [Development of nitrooxidative stress and inflammatory processes in rats of different ages affected by tobacco smoke]. Svit medytsyny ta biolohii. 2017;4(62): 145-49. Ukrainian.

22. Orlova VD, Khrenov OA. [Influence of long-term smoking on LPS-induced synthesis of proinflammatory cytokines TNF-A and IL-1B by mononuclear leukocytes in patients with chronic pulmonary and chronic heart failure]. Zdobutky klinichnoi i eksperymentalnoi medytsyny. 2012;(1): 108-10. Ukrainian.

23. Nenasheva NM. [Bronchial asthma and smoking]. Effektivnaya farmakoterapiya. 2013;(10): 4-14. Russian.
24. Barbieri SS, Zacchi E, Amadio P, Gianellini S, MusZ soni L, Weksler BB, Tremoli E. Cytokines present in smokers' serum interact with smoke components to enhance endothelial dysfunction. Cardiovascular Research. 2011; 90(3): 475-83.

25. Hart K, Haugen A, Zienolddiny S. Allele-specific induction of IL1B- 31 T/C promoter polymorphism by lung carcinogens. Mutation Research/Genetic Toxicology and Environmental Mutagenesis. 2008;656: 8-14.

26. Hou L, Huang J, Lu X, Wang L, Fan Z, Gu D. Polymorphisms of tumor necrosis factor alpha gene and coronary heart disease in a Chinese Han population: interaction with cigarette smoking. Thrombosis Research. 2009;123(6): 822-6.

27. Yanbaeva DG, Dentener MA, Creutzberg EC, Wesseling G, Wouters EF. Systemic effects of smoking. Chest. 2007;131(5): 1557-66.

28. Asfandiyarova NS. [Nicotine and the immune system]. Immunopatologiya, Allergologiya, Infektologiya. 2018;3: 12-6. Russian.

29. Asmolov OK, Rybak TA, Smolska IM, Herasymova NA, Baburina OA, Asmolov AK, Rybak TA, Smol'skaya YN, Baburyna EA. [Influence of smoking on the pathogenesis of chronic obstructive pulmonary disease]. Odes med zhurn . 2008;6(110): 70-2. Ukrainian.

30. Rudyk MP, Pozur VV, Opeyda YV, Voyeykova DO, Khranovs'ka NM, Fedorchuk OH, Berehova TV, Ostapchenko LI. [Modulatory effects of sodium glutamate on circulating phagocytic cell functions in rats in vivo and in vitro]. Dopovidi Natsionalnoi akad nauk Ukrainy. 2017;5: 97-89. Ukrainian

31. Shapiro H, Lutaty A, Ariel A. Macrophages, meta-inflammation, and immuno-metabolism. The Scientific World Journal. 2011;11: 2509-29.

32. Golovach IYU. [Nuclear factor $\mathrm{KB}(\mathrm{NF}-\mathrm{kB})$ as an important pathogenetic factor and a new target in the treatment of rheumatic diseases]. Ratsionalnaya farmakoterapiya. 2012;3(24): 51-46. Russian.

33. Xu L, Sun J, Lu R, Ji Q, Xu JG. Effect of glutamate on inflammatory responses of intestine and brain after focal cerebral ischemia. World Journal of Gastroenterology: WJG. 2005;11(5): 733-36.

34. Butcher BA, Kim L, Johnson PF, Denkers EY. Toxoplasma gondii tachyzoites inhibit proinflammatory cytokine induction in infected macrophages by preventing nuclear translocation of the transcription factor NF-KB. The Journal of Immunology. 2001;167(4): 2193-201.

35. Schölzke MN, Potrovita I, Subramaniam S, Prinz $\mathrm{S}$, Schwaninger M. Glutamate activates NF-KB through calpain in neurons. European Journal of Neuroscience. 2003;18: 3305-10.

Отримано 02.02.20 